\title{
Studying DNA Damage Biomarkers and Early Detection Cancer Together With an Artificial Intelligence Approach Would Be Innovative For Preventive Medicine
}

\author{
Elio A Prieto González* \\ Center of Higher Studies in Human and Health Sciences, Open Interamerican University, Argentina
}

Submission: May 10, 2018; Published: May 15, 2018

"Correspondence Address: Elio A Prieto González, Center of Higher Studies in Human and Health Sciences, Open Interamerican University, Buenos Aires, Argentina, Email: Elio.Prietto@Vaneduc.edu.ar

\section{Opinion}

When oncologic preventive issues are addressed, are so often considered in the environment of an early detection procedure in a hospital or in the office of a general practitioner, concerned for the health of its fellow citizens. Cancers from the main localizations must be diagnosed as early as possible in what have become a central dogma for Oncology. Colon, lung, breast esophagus or prostate neoplasm, are diagnosed earlier as techniques are developed to detect variations in circulating DNA, to get computer generated high resolution images or to find abnormal antigens. It is true that an early detection results in better treatment outcomes, with improved patient's survival and life quality, a tendency that seems to support earlier detection as the Holly Grail of cancer treatment.

Prevention is a powerful tool for cancer management, which does not only affect survival rates but also limits the secondary adverse effects when the treatment courses are reduced. Early detection of an already developing cancer allows more efficacious oncotherapy. But, this is not prevention. Prevention is a previous stage issue, a collection of approaches, warnings and educative attempts that allow us to put the brakes before the situation reach the subclinical horizon. Prevention is a too serious issue, paraphrasing Clemenceau, to let only in physician's hands that why mathematicians have been increasingly involved in this area. Cancer prevention is far beyond early detection, but in the opposite direction.

Prevention is a collective enterprise, but must be guided after facts; an outstanding class of those facts is biomarkers, not only for subclinical cancer detection but also for monitoring DNA damage or exposition to carcinogens. Genotoxicity biomarkers are quantifiable and could lead to identification of those warning signals that expresses the odds of being a cancer patient among the population at risk. A probable successful approach should combine the evaluation of different biomarkers of DNA damage and those for early cancer detection, in the same populations. This could help in the monitoring and calibration of preventive measures tailored to a community or even at patient's level.

There are DNA damage or mutation biomarkers that have been widely studied in North Europe and Italian projects that in the case of chromosomal aberration have proven a real predictive capacity (Nordic Study Group on the Health Risk of Chromosome Damage [1] Bonassi et al. [2]. There are others like comet assay that enlarge the spectra of cells that can be studied including those from bronchi, gut or buccal cavity, but this technique nowadays are still lacking the strength for prediction of cancer risk. Results of those tests are quantitative and allow the evaluation of its variations in a target population in connection with environmental or nutritional changes.

Those variations in mutational and genotoxic endpoints are expected to be diverse but to follow similar time and spatial tendencies that can be described as a swarm, and could help to define more precisely the levels of cancer risks Song et al. [3]; Nikitaki et al. [4]; Mavragani et al. [5]. On the other side, biomarkers for early cancer are also expected to behave as a swarm, and indeed some of those biomarkers have been identified following a mathematical swarm approach Meng [6]; Martinez et al. [7]; Best et al. [8]. Our assumption is that variations in the responses and values of both categories of biomarkers, increases and decreases in each time point and over defined spatial coordinates. The coherence in the direction of variations resembles a swarm that moves slowly, and gives us the opportunity to exert some influence over its movements, what could mean preventive actions Song et al. [3]; Chatterjee \& Walker [9].

There are evidences of a concordance in changes in biomarkers from genetic damage that resembled a slow swarm and a similar behavior has been observed in biomarkers for 


\section{Cancer Therapy \& Oncology International Journal}

early cancer detection. The fact that the first category is before, and the second is after the beginning of the cancer initiation and progression, is crucial for the analysis of the importance of studying both kinds of biomarkers together. As a way to enlighten their relationships, allowing to knowhow the variations in the first set, could foresee variations in the second in defined populations Andrews et al. [10]; Fukushima et al. [11]. Artificial intelligence algorithms developed and established over the real possibility of processing high number of data have allowed identification of patterns of variations and their relationships that are interpreted according to its biological significance, but can also help in the discovery of new significances in those links identified through IA methods. That huge amount of data can be managed with artificial intelligence procedures, in order to investigate that "slow swarm behavior" in the variations in both sets of biomarkers. The changes in the direction of those swarms must be related with the changes in cancer incidence.

Mathematic algorithms for the prediction of which one is the best combination of variables, with the purpose of predict tendencies in the early detection biomarker's swarm and ultimately to force that swarm to go downward, results in a research avenue that must be travelled, wherever and as soon as possible.

\section{References}

1. Nordic Study Group on the Health Risk of Chromosome Damage (1991) A Nordic data base on somatic chromosome damage in humans. Mutat Res 241(3): 325-337.

2. Bonassi S, Hagmar L, Strömberg U, Montagud AH, Tinnerberg H, et al. (2000) for the European Study Group on Cytogenetic Biomarkers and Health Chromosomal Aberrations in Lymphocytes Predict Human Cancer Independently of Exposure to Carcinogens. Cancer Res 60: 1619-1625.

3. Song Z, von Figura G, Liu Y, Kraus JM, Torrice C, et al. (2010) Lifestyle impacts on the aging-associated expression of biomarkers of DNA damage and telomere dysfunction in human blood. Aging Cell 9(4): 607-615.

4. Nikitaki Z, Hellweg CE, Georgakilas AG, Ravanat JL (2015) Stressinduced DNA damage biomarkers: applications and limitations. Frontiers in Chemistry 3: 35.

5. Mavragani IV, Nikitaki Z, Souli MP, Aziz A, Nowsheen S, et al. (2017) Complex DNA Damage: A Route to Radiation-Induced Genomic Instability and Carcinogenesis. Cancer 9(7): E91.

6. Meng Y (2006) A swarm intelligence based algorithm for proteomic pattern detection of ovarian cancer. IEEE Symp on Computational Intelligence and Bioinformatics and Computational Biology (CIBCB), pp. 1-7.

7. Martinez E, Alvarez MM, Trevino V (2010) Compact cancer biomarkers discovery using a swarm intelligence feature selection algorithm. Comput Biol Chem 34(4): 244-250.

8. Best MG, Sol N,'t Veld SG, Vancura A, Muller M, et al. (2017) Swarm Intelligence-Enhanced Detection of Non-Small-Cell Lung Cancer Using Tumor-Educated Platelets. Cancer Cell 32(2): 238-252.

9. Chatterjee N, Walker GC (2017) Mechanisms of DNA damage, repair and mutagenesis. Review. Environ Mol Mutagen 58 (5): 235-263.

10. Andrew AS, Nelson HH, Kelsey KT, Moore JH, Meng AC, et al. (2006) Concordance of multiple analytical approaches demonstrates a complex relationship between DNA repair gene SNPs, smoking and bladder cancer susceptibility. Carcinogenesis 27(5): 1030-1037.

11. Fukushima S, Gi M, Kakehashi A, Wanibuchi H, Matsumoto M (2016) Qualitative and quantitative approaches in the dose-response assessment of genotoxic carcinogens. Review. Mutagenesis 31(3): 341 346.

\section{Your next submission with Juniper Publishers will reach you the below assets}

- Quality Editorial service

- Swift Peer Review

- Reprints availability

- E-prints Service

- Manuscript Podcast for convenient understanding

- Global attainment for your research

- Manuscript accessibility in different formats

( Pdf, E-pub, Full Text, Audio)

- Unceasing customer service

Track the below URL for one-step submission

https://juniperpublishers.com/online-submission.php 